\title{
PRÁXIS DE JESUS E PRÁXIS DA LIBERTAÇÃO À LUZ DO ANTICRISTO DE NIETZSCHE
}

\author{
Jesus práxis is the liberation praxis of the \\ Antichrist of Nietzsche
}

\author{
Edélcio Ottaviani
}

Doutor em Filosofia pela Universidade Católica de Louvain (Bélgica), professor da PUCSP e coordenador do Curso de Filosofia do UNIFAI.

e-mail: edelcioottaviani@uol.com.br

\section{Resumo}

O artigo procura resgatar o sentido da práxis no pensamento nietzschiano e demonstrar como ele se associa à compreensão socrática de não submeter a práxis à teoria, segundo o pensamento desenvolvido por Hannah Arendt, à luz do estudo desenvolvido por Jacques Taminiaux. Procuramos associar esta reflexão a um momento particular da história latino-americana, em que milhares de pessoas foram perseguidas, torturadas e assassinadas por quererem realizar na prática um projeto de libertação. Neste sentido, apresentamos a práxis da libertação como uma forma concreta de liberação da alienação e como ação concreta de autoformação do sujeito em seu combate às ditaduras militares, defensoras incontestes da violência inescrupulosa do capital. Numa atitude de provocação, queremos demonstrar que a Teologia e práxis da libertação, inspiradas na práxis de Jesus, não se manifestaram como forças contrárias à vida e instrumentos de alienação, mas instrumentos incontestes de libertação.

Palavras-chave: Práxis de Jesus; Anticristo; Ressentimento; Decadência; Libertação e ttransmutação dos valores. 


\section{Abstract}

This article attempts to rescue the meaning of the praxis on nietzchean thought and to demonstrate how it is associated to the socratic understanding of one not submitting the praxis to the theory, according to the thought developed by Hannah Arendt, enlightened by the studies produced by Jacques Taminiaux. We tried to associate this reflexion to a specific moment of the Latin American history, in which thousands of peoplewere persecuted, tortured and murdered for desiring to accomplish, in practice, a project ofliberation. In this sense, we present the praxis of liberation as a concrete way of freedom, of the alienation and as a concrete action of individual's self formation in his fight against military dictatorships which were uncontested defenders of unscrupulous violence of the capital. In a provoking attitude we want to demonstrate that the theology and the praxis of liberation, inspired in Jesus's praxis, were not revealed as opposite forces to life and alienation instruments but as unrefuted instruments of freedom.

Keywords: Jesus's Praxis; Anti christ; Resentment; Decadence; Liberation and transmutatiom of values.

\section{Introdução}

Este artigo procura resumir a temática abordada por mim por ocasião da redação de minha tese doutoral, versando sobre a relação entre Filosofia e Religião a partir do pensamento de Nietzsche como contraponto crítico à práxis libertária da Igreja Católica Latino-americana fundamentada na Teologia da Libertação, cuja epistemologia está baseada num pensar filosófico submetido a uma situação de opressão. Procurei demonstrar como a práxis libertadora das Comunidades Eclesiais de Base emergiu no contexto latino-americano dos anos 70 e 80 do século passado como uma Vontade de Potência a favor da vida. O artigo procura resgatar o sentido da práxis no pensamento nietzschiano e demonstrar como ele se associa à compreensão 
socrática de não submeter a práxis à teoria, segundo o pensamento desenvolvido por Hannah Arendt, à luz do estudo desenvolvido por Jacques Taminiaux. Para Hannah Arendt, e da mesma forma para Nietzsche, a práxis jamais deve estar separada da teoria, ainda que não se deva confundi-las. Uma e outra se apresentam como elementos essenciais ao ser humano que deseja afirmar e aprimorar sua condição de vida. É o que apresentamos ao associar esta reflexão a um momento particular da história latino-americana, em que milhares de pessoas foram perseguidas, torturadas e assassinadas por quererem realizar na prática um projeto de libertação. Neste sentido, apresentamos a práxis da libertação como uma forma concreta de liberação da alienação e como ação concreta de autoformação do sujeito em seu combate às ditaduras militares, defensoras incontestes da violência inescrupulosa do capital. O mais significativo é que esta resistência à ditadura militar, seguida de uma organização popular fomentando a reabertura política, a defesa dos direitos humanos e de um reavivamento do movimento sindical, deu-se de forma concreta na América Latina por intermédio também da Religião: teologia e práxis da libertação, inspiradas na práxis de Jesus, enquanto antíteses das forças contrárias à vida e dos instrumentos de alienação; enquanto instrumento praxiológico de libertação.

\section{Considerações gerais sobre a práxis de Jesus em o anticristo de Nietzsche}

\section{A concepção de práxis segundo Nietzsche}

No que diz respeito às obras de Nietzsche, bem como em seus escritos publicados postumamente, não há nenhum momento em que a práxis seja tratada exaustivamente como nos escritos que versam sobre a moral, a verdade, a vontade ou o pensamento. Turco Livieri, no seu Léxico dos conceitos nietzschianos, só consagra cinco linhas a este termo, citando praticamente nove aforismos, ao passo que no conjunto de uma obra de centenas de páginas, três são dedicadas ao conceito "Vida" (TURCO, 1982). Em relação às obras publicadas, o aforismo 372 da Gaia Ciência fala a seu respeito quando menciona a inclinação sensualista dos filósofos presentes e futuros de sua época, que o são em relação à práxis, à prática, mas que não são em relação à teoria, pois julgam a sensualidade um verdadeiro perigo em relação ao seu mundo, quer dizer "o mundo das idéias". Já no Anticristo, o termo aparece quando Nietzsche faz referência à inexistência de uma articulação teórica na práxis vivida do Cristo. 
Porém, é nos Fragmentos Póstumos datados da primavera de 1888 que ele aponta para a sua noção de práxis ao não querer vê-la separada da teoria:

Perigosa distinção entre "teoria"(theoretisch)e "prática" (praktisch), por exemplo em Kant, mas também nos antigos.

- eles fazem como se fosse a pura intelectualidade que lhes apresentasse os problemas do conhecimento e da metafísica.

- eles fazem como se, não importa qual seja a resposta teórica, a prática devesse ser julgada segundo seus próprios critérios.

Contra o primeiro ponto, eu dirijo meu ponto de vista sobre a psicologia dos filósofos: sua especulação, a mais abstrata, toda sua "intelectualidade" não é mais do que a última e pálida impressão de um fato fisiológico: falta aí toda a característica voluntária, tudo é instinto, tudo é encadeado sobre certas vias (Alles ist Instinkt, Alles ist von vorn herein in bestimmte Bahnen gelenkt [...])

- contra o segundo ponto, eu pergunto se nós conhecemos, para bem agir, um outro método que sempre pensar: pensar é uma maneira de agir, e agir pressupõe sempre um pensamento. Temos o poder de julgar o valor de um modo de vida de outra forma que não julgando o valor de uma teoria, por indução, por comparação? [...].

"Nós devemos agir e conseqüentemente temos necessidade de uma regra de conduta", disseram os céticos da Antiguidade. Tomar por um argumento de urgência e uma decisão, tomar por verdade o que quer que seja!

"Nós não devemos agir" - disseram os mais conseqüentes de seus irmãos, os budistas, e eles inventaram uma regra de conduta permitindo o desprendimento da ação [...].

Conformar-se aos outros; viver como vive o "homem ordinário", ter por bel e bom o que se toma comumente por bel e bom: é a submissão ao instinto de rebanho.

Deve-se levar sua coragem e seu rigor para bem longe para ressentir como uma vergonha uma tal submissão. Não viver com dois pesos e duas medidas! [...] Não separar teoria e prática (Nicht Theorie und Práxis trennen). (NIETZSCHE, 1992a, p. 78-79).

Por meio desse pensamento, podemos ver a vertente crítica de Nietzsche em relação à tendência de separar a práxis da teoria ou de julgar a primeira inferior à segunda, ou melhor; de conceber a força da práxis infinitivamente menor que a teoria. No que diz respeito a Kant, Nietzsche faz menção à tendência idealista do filósofo que coloca o a priori da razão independente de toda sensibilidade, de toda inclinação instintiva ou de toda 
vontade. Como bom intérprete e assimilador da intuição schopenhaueriana, Nietzsche não menospreza as inclinações do coração humano que impulsionam a razão à criação de elaborações teóricas que as legitimem. Afinal, estas últimas não são mais do que construções racionais legitimando a aquisição do que realmente quer a vontade. Como diz Nietzsche neste aforismo: Alles ist Instinkt. Não é possível desvencilhar as construções teóricas do seu contexto histórico e da confluência de vontades imanentes que lhe são inerentes e que contribuem para sua constituição. Desconsiderar tudo isso é afirmar ingenuamente que se podem erigir teorias, até mesmo morais, independentemente da sensibilidade e da realidade histórica na qual estão inseridas.

Por outro lado, o ser humano desenvolveu sua racionalidade a ponto de também influir sobre a vontade. Hierarquizar as pulsões, as inclinações, é próprio das vontades afirmativas em busca de realização de uma meta, de um projeto, de um fim, como pondera Eugen Fink ao interpretar o pensamento nietzschiano sobre a Vontade de Potência. É a vertente apolínea ordenando e dando forma ao eterno fluxo dionisíaco do devir.

O pensamento de Nietzsche a respeito da vinculação entre teoria e práxis tem uma relação intrínseca com $a$ interpretação, $o$ instinto vital e a hierarquização dos valores, elementos essenciais da Vontade de Potência que se afirma ao afirmar o que propôs a si mesma. Segundo ele, a racionalidade, enquanto parte funcional da vontade afirmativa, depois de ter mapeado a realidade num determinado momento, fixa-a e aponta para o que deve ser feito não só em favor da manutenção da vida, mas, sobretudo, em favor da sua excelência.

Entretanto, a razão que fixa é a mesma que compreende a necessidade de adequar a composição teórica aos novos dados oferecidos pela realidade dinâmica (Wirklichkeit). Novos momentos possibilitam a irrupção de novos fenômenos que, por sua vez, exigem uma recomposição teórica com vistas à melhor ação. Afinal, para Nietzsche, é uma quimera da razão achar que se possa fixar de uma vez por todas o que pertence ao fluxo contínuo das variações.

Nietzsche, enquanto crítico do dualismo moral, não aceita que o ser humano continue a agir como um ser cindido e frustrado por causa de sua inoperância em aplicar à realidade o plano ideal. ${ }^{1}$ Zaratustra, falando a seus discípulos para que permaneçam fiéis à terra, não é outro senão o próprio Nietzsche dirigindo-se aos filósofos do futuro para não se aterem às elaborações

1 O dualismo na moral se caracteriza pela indicação das condições ideais da ação, mas que no momento de sua efetivação encontra os subterfúgios para driblar a sua impraticável realização. 
metafísicas de um mundo ideal julgando negativamente o mundo real. Pela boca de Zaratustra, Nietzsche denuncia o caráter niilista do pensamento moderno que pretende determinar de uma vez por todas a verdade do mundo fenomenal e conseqüentemente o que se deve fazer no campo moral.

Hannah Arendt, ao refletir sobre a condição humana e a fragilidade inerente ao universo da práxis, parece ter chegado à mesma conclusão de Nietzsche, pois, num de seus manuscritos, ela escreve:

It is human to act to want act; it is human to think and to want to think. Wherever you don't have them combined, thought they are in a sense opposite, in the living man, you have either thoughtless action or impotent thought. It is always life that offers the solutions ${ }^{2}$. (ARENDT, 2001, p. 44).

Segundo Jacques Taminiaux, o que leva Hannah Arendt a escrever sobre o valor inerente à práxis é a sua determinação em combater as teses heideggerianas, contidas na sua Ontologia Fundamental, que atribuem uma preeminência do homem contemplativo (bios theorétikos) sobre o homem de ação (bios práktikos ou politikós). Ao se inspirar nas teses platônicas contidas na República sobre o Filósofo-rei ou o Rei-filósofo, Heidegger afirma que o bios theorétikos é aquele que está mais próximo de desvelar o ser do ente e apontar para o resto da humanidade o caminho da existência autêntica e, conseqüentemente, da felicidade, pois ele não é absorvido pelas preocupações do mundo cotidiano. Parece no mínimo ingênuo que esta leitura das teses platônicas contempladas por Heidegger o tenha levado a ver em Hitler o guia, o Führer, da restauração e da organização da Alemanha nos anos que sucederam a Primeira Guerra Mundial.

Numa posição inversa, a de judia e de perseguida pela Gestapo, Hannah Arendt toma partido das teses aristotélicas que salvaguardam o valor da práxis enquanto desveladora do ser do homem (Dasein), pois é agindo e falando no domínio público (Ágora) que o ser humano realmente aparece e mostra o que ele realmente é.

Hannah Arendt, a exemplo de Nietzsche, que viu na cultura e no pensamento gregos a chave para retirar a humanidade do niilismo que

2 "É humano agir e é humano querer agir; é humano pensar e querer pensar. Lá, onde estas duas coisas não podem ser combinadas, ainda que num certo modo elas sejam opostas, no homem vivo, encontra-se ou bem uma ação irrefletida ou bem um pensamento impotente. É sempre a vida que oferece as soluções.

Rev. Filos., v. 19, n. 24, p. 79-109, jan./jun. 2007 
caracterizou o final do século XIX, volta-se para os clássicos gregos a fim de compreender e superar o non-sense existencial que emergiu na Europa a partir da Segunda Grande Guerra e do Holocausto dos judeus.

No tópico seguinte, à luz de Jacques Taminiaux, abordaremos as tradições platônica e aristotélica sobre a práxis e veremos como o pensamento de Hannah Arendt, quanto o aforismo de Nietzsche aproximam-se mais de Aristóteles e se distanciam daquele de Platão.

\section{Elementos do pensamento aristotélico sobre concepção de práxis em Nietzsche}

Segundo Hannah Arendt, Platão tomou consciência da distinção grega entre homem teórico (bios theorétikos) e homem político (bios politikós), aquele que age para o bem da pólis (eupraxia), logo após o processo de Sócrates, em outros termos:

Conclui Arendt, a cidade não sabia o que fazer com um filósofo e os amigos não sabiam o que fazer com a argumentação política. Este é um dos aspectos da tragédia testemunhada pelos diálogos de Platão. Somente um dos aspectos, pois logo que ele conclui a partir do processo de Sócrates que a validade da persuasão deve ser colocada em dúvida, Platão acrescenta a esta denúncia uma outra: a validade da doxa (opinião), já que a doxa socrática foi desfeita pela maioria das doxas dos atenienses. Neste sentido, a doxa como tal deve ser desprezada e é a verdade que deve substituí-la, quer dizer, a busca de critérios absolutos: "Ora, insiste Arendt, a oposição entre verdade e opinião era certamente a conclusão a mais antisocrática que Platão poderia tirar do processo de Sócrates". (TAMINIAUX, 1992, p. 215).

O discípulo que tinha aprendido com seu mestre a arte da maiêutica, valorizando, por meio do diálogo, a força ou a fraqueza dos argumentos em discussão, e conseqüentemente a sua veracidade, ficou desesperado e decepcionado diante da incapacidade do filósofo em persuadir os juízes de sua inocência. Esta constatação levou Platão a duvidar da eficácia de alguns princípios de seu mestre, que tinha capitulado em sua tentativa de persuadir seus amigos quanto às razões políticas da acusação, impulsionandoo a aceitar a sua condenação. Eis o porquê da fundação da Academia e de seu afastamento do espaço público: dela só farão parte aqueles que estão realmente 
comprometidos com a busca da verdade, à diferença das escolas sofísticas, cujos membros são norteados por outros interesses. Segundo Heidegger, é no diálogo O Sofista que Platão denuncia o caráter nocivo da doxa (opinião), ligada à primeira impressão e, ao que aparece primeiramente, por levar o ser humano (Dasein) a agir fora da verdade.

Segundo Hannah Arendt, não é o que pensa Aristóteles, pois este se esforçará por demonstrar na Ética a Nicômaco o valor metafísico do bios politikós. Ainda que propenso a sucumbir aos artifícios da doxa, este está mais próximo de revelar o ser inerente à pólis. Como já aludimos anteriormente, é somente agindo e falando no seio do domínio público que o homem realmente aparece, se desvela, e mostra o que ele é. Ao aproximar-se da concepção aristotélica, Hannah Arendt se afasta de Platão e conseqüentemente de Heidegger, legitimando teoricamente a manutenção do espaço público contra todo autoritarismo.

Para Platão, existem duas formas de vida: a ativa e a contemplativa. Mais do que opostas, estas duas maneiras de viver são complementares, ainda que a primeira seja inferior à segunda. Conforme o fundador da Academia, todo homem que se consagra à vida contemplativa e se dispõe a procurar o Bem supremo, tem necessidade de ser abastecido regularmente de certa quantidade de bens (comida e bebidas), assim como de dispor de uma habitação e de alguns utensílios. Isto supõe, é certo, sua produção e sua manutenção. Por outro lado, o bios teorétikos, aquele que procura a verdade das coisas por detrás das aparências e cuja sabedoria está mais apta a governar ou a aconselhar os governantes da cidade não pode ter sua atenção desviada do mundo das idéias e deve, conseqüentemente, estar livre das preocupações cotidianas. É assim que a vida ativa, cuja "dignidade específica se esgota na ajuda que ela oferece aos fins contemplativos", ${ }^{3}$ aparece na República como um "meio" a serviço da contemplação.

Por estar mais próxima do modelo pensado pelo agente (homem de ação), a ação de produzir (poiésis) é colocada num grau acima da práxis, que ao se efetivar no domínio público nem sempre se coaduna com o que havia sido pensado anteriormente. Há uma defasagem entre o que foi pensado e o que está sendo realizado.

Desviando seu olhar da atividade do cidadão, o que segundo Hannah Arendt marcava a excelência da pólis, Platão classifica a práxis num nível inferior à poiésis pelo fato de que a atividade do artesão está mais próxima do mundo da contemplação, pois "ele toma a priori um modelo, um arquétipo,

TAMINIAUX, 1992, p. 39.

Rev. Filos., v. 19, n. 24, p. 79-109, jan./jun. 2007 
uma idéia, e seu olhar se atém a ele durante todo o processo de manipulação e acabamento do produto"; 4 ao passo que a práxis pode ou não se realizar plenamente segundo o modelo pensado (eidos).

Apresentada a concepção de práxis em Platão, vejamos agora a definição de práxis apresentada por Aristóteles e sua diferenciação das duas outras espécies de ação.

Conforme a interpretação de Aristóteles, a práxis caracteriza a ação do cidadão na pólis em vista do melhor fim, ou seja, do bem e da felicidade para todos os membros da cidade. Ela possui um par, a phronésis (sabedoria/ prudência), que procura orientá-lo na identificação da ação justa ou ação na justa medida, para a qual é necessária a boa vontade a fim de efetivá-la, pois para realizá-la não basta identificá-la. Diferentemente do que vemos acontecer com a poiésis, a práxis não apresenta a defasagem entre o produtor e seu produto. No homem ativo, o bios práktikos, o fim de sua ação (phronésis) não recai sobre alguma coisa fora dele (o objeto produzido), antes, é o seu ser mesmo a razão do seu agir. Nele, o princípio (arché) e a finalidade (telos) coincidem. Assim, bem agir em vista do bem da pólis (eupraxia) é para Aristóteles o fim para o qual tende o bios práktikos ou politikós.

Poiésis, por sua vez, revela um comportamento de fabricação ou de produção caracterizado pelo saber-fazer (techné). Nesta atividade, o princípio de produção, o eidos, reside no agente produtor. É nele, e não no produto, que se encontra o tipo ou o modelo da obra ou do produto. Por outro lado, o telos (alvo e fim) se encontra no produto e não no produtor. Logo que o produto atinge sua realização plena (energéia ou entelechéia), ele se torna independente do produtor e se submete a uma diversidade de fins que transcendem a finalidade que the destinava seu autor. É por causa desse desequilíbrio existente entre arché et poiésis que Aristóteles classifica esta última num nível inferior em relação à práxis.

No entanto, se para Platão a atividade poiética, ou seja, a atividade de fabricação apresenta um caráter de estabilidade sendo, portanto, mais próxima do mundo das idéias eternas e imutáveis, para Hannah Arendt, ela apresenta também um traço de instabilidade. Afinal, o fim (telos) de sua atividade é centrado sobre a realização de um objeto que estará separado de todo contato com o produtor, podendo servir a outros fins, a partir do momento em que outra pessoa se apresenta como seu legítimo possuidor. Na verdade, a poiésis "é incapaz de tomar verdadeiramente em vista aquilo mesmo que ela constitui, o mundo precisamente."

TAMINIAUX, 1992, p. 39.

TAMINIAUX, 1992, p. 39.

Rev. Filos., v. 19, n. 24, p. 79-109, jan./jun. 2007 
Esta atividade está intrinsecamente determinada pela mentalidade utilitária do homem poiético ao reger os meios e determinar o processo de fabricação. Ela se inscreve numa sequiência de meio-fim que transcende a "finalidade" pensada pelo artesão. É assim que esta mentalidade utilitária, privando cada coisa de sua dignidade intrínseca, "destrói toda a significação permanente e corrói, por conseguinte, a objetividade e a consistência deste habitat que é o mundo."

Para Hannah Arendt, a única atividade que transcende o funcionalismo dos bens de consumação e a pura utilidade das coisas de uso é a práxis. $^{7}$

É por meio da ação (práxis) e da palavra (lexis) que o indivíduo foge à condição efêmera dos entes, submissos ao eterno retorno da natureza (zoé), e se afirma como a vida de alguém, marcada por acontecimentos particulares que podem ser contados.

Começo de alguém, o nascimento mergulha o indivíduo num emaranhado de relações humanas marcado pela pluralidade de indivíduos, diferentes e semelhantes ao mesmo tempo. Segundo Hannah Arendt:

Se os homens não fossem iguais eles não poderiam se compreender uns aos outros, nem compreender os que os precederam, nem preparar o futuro e prever as necessidades daqueles que virão depois deles. Se os homens não fossem distintos, cada ser humano distinguindo-se de todo outro ser presente, passado ou futuro, não teria necessidade nem de palavra nem de ação para se fazer compreender. Seria suficiente emitir sinais e ruídos para comunicar os desejos e as necessidades imediatas e idênticas. (ARENDT, 1988, p. 231-232).

Mas é por meio da ação e da palavra que o homem é inserido efetivamente no mundo e aparece a outros indivíduos, eles mesmos não menos aparentes. Ele é introduzido como que por um segundo nascimento no qual ele confirma e assume o fato bruto de sua aparição física e original. ${ }^{8}$ Esta malha de relações, em razão dos novos nascimentos, introduzindo nos negócios humanos novos efeitos, é continuamente renovada. Esta renovação, na qual cada um que age é ao mesmo tempo um paciente e um agente, descarta toda previsibilidade da ação e determina assim o caráter intrinsecamente ambíguo e frágil da práxis.

6 TAMINIAUX, 1992, p. 39.

TAMINIAUX, 1992, p. 44.

8 TAMINIAUX, 1988, p. 233.

Rev. Filos., v. 19, n. 24, p. 79-109, jan./jun. 2007 
Diferentemente da poiésis, cujo artesão possui a priori o modelo do produto a fabricar, o sentido atribuído pela práxis aos fenômenos só é determinado no contexto e movimento mesmo da ação. Segundo Arendt, se o sentido fosse dado anteriormente e de maneira unificada, ele seria uma ameaça para a pluralidade renovada e para a incessante partilha de vozes inerentes à comunidade isonômica.

Assumir a fragilidade da práxis como condição a salvar a forma de agir mais própria ao ser humano, eis o que diferencia Arendt de Platão e de Heidegger. É a práxis que torna possível o aparecer do ser, enquanto que ele aparece por meio dos atos e das palavras e a partir do momento em que ele atribui um sentido aos fenômenos. O ser do homem faz aparecer o ser do mundo seguindo as determinações racionais da comunidade humana.

Segundo Arendt, o grande problema que toca os filósofos (Aristóteles também não escapou) é que eles encontram profundas afinidades entre a contemplação (theoria) e a fabricação (poiésis), acreditando "que elas não se opõem sem equívoco como a contemplação e ação". ${ }^{9}$ Procurando clarear a origem desta predileção pela contemplação ao detrimento da ação na tradição filosófica, Arendt chama nossa atenção sobre a experiência do thaumazein em Sócrates e sobre a interpretação posterior que lhe deu Platão.

"Começo de toda filosofia", o thaumazein se caracteriza pelo pensamento fechado no seu recolhimento absoluto, traduzido pela perfeita imobilidade da vista do pensador. Diferentemente de Platão, cuja contemplação correspondia mais às experiências do artesão vendo diante de seu olhar interior a forma do modelo segundo o qual ele fabricará o objeto, o maravilhamento mudo de Sócrates convidava seus discípulos a passarem em meio ao mundo, estando momentaneamente afastado dele.

Para Arendt, a contemplação que gozava Sócrates é de uma ordem completamente diferente daquela de Platão. Para Sócrates, o thaumazein é a realização paradoxal de pertença e de distanciamento do mundo. Nele, Arendt vê o contrário do pensador profissional: a tendência a se afastar do mundo real ou a ditar regras ao conjunto da sociedade. Unificando duas paixões contraditórias, pensamento e ação, Sócrates reclama somente o direito de refletir as opiniões dos outros, convidando-os a fazerem o mesmo. Sem pretender aconselhar politicamente as pessoas do poder ou de governar ele próprio os homens, ele lhes ensinava, com sua forma de agir, a não se submeter à dominação (TAMINIAUX, 1992).

9 ARENDT, 1988, p. 377. 
Segundo Arendt, nós poderíamos dizer que a pertença ao mundo e o distanciamento dele formam a tensão à qual são chamados todos os que querem alcançar o cume da condição humana. Se Arendt opõe o pensamento à ação, é para que não haja nenhum risco de submeter a práxis à contemplação. Para ela, estas duas dimensões não podem estar separadas e devem permanecer no mesmo nível, sem que se estabeleça entre elas uma hierarquia.

A interpretação de Hannah Arendt ajudou-nos a iluminar o pensamento de Nietzsche, cujos fundamentos ele não nos evidenciou. Certamente os elementos apresentados por Hannah Arendt e sistematizados por Jacques Taminiaux trouxeram à luz aquilo que Nietzsche certamente conhecia. Com grande probabilidade, estes elementos o fizeram distanciar-se do pensamento platônico e a pedir que não haja separação entre teoria e práxis. É certo, porém, que a opinião que Arendt tem a respeito de Sócrates não coincide com a que Nietzsche apresenta no Crepúsculo dos Ídolos. Arendt procura diferenciar o que é a pessoa de Sócrates e o que lhe é atribuído enquanto pensamento e ação por Platão. Mesmo assim, a idéia do thaumazein como retração e pertença ao mundo vai ao encontro da tônica apresentada pelo aforismo de Nietzsche (1992a):

Se conformar aos outros; viver como vive o "homem ordinário", ter por bel e bom o que se toma comumente por bel e bom: é a submissão ao instinto de rebanho.

Deve-se levar sua coragem e seu rigor para bem longe para ressentir como uma vergonha uma tal submissão. Não viver com dois pesos e duas medidas! [...] Não separar teoria e prática (Nicht Theorie und Práxis trennen). (NIETZSCHE, 1992a, p. 79).

\section{O Anticristo e suas considerações sobre a práxis de Jesus}

O Anticristo, obra concebida para fazer parte de uma obra maior (Vontade de Potência), traz como subtítulo: Imprecação contra o Cristianismo e entre parêntesis [Inversão de todos os valores] (COLLI, MONTINARI, 1992). Foi composta para ser o primeiro capítulo de uma obra sistemática cujo objetivo era propor uma transmutação, inversão radical de todos os valores oriundos principalmente da moral judaico-cristã. A crítica radical que ele opera, beirando o ódio e, quem sabe, o ressentimento, tem por escopo a desconstrução da metafísica cristã, cuja influência no pensamento filosófico ocidental culminou no niilismo europeu. 
Nietzsche passa às vistas todos os grandes expoentes do pensamento ocidental, tais como Descartes, Pascal, Kant e Hegel e até mesmo seu grande mestre da juventude, Schopenhauer, apontando para a influência negativa da teologia cristã em seus pensamentos. Segundo Nietzsche, em Descartes vemos a crença no Deus perfeito como base a uma forma correta de se pensar, como se no "eu penso" não houvesse os limites do ato de pensar e da historicidade do sujeito que pensa; em Pascal, a liberdade do pensamento livre de sistemas sucumbindo ao peso da conversão; em Kant, o gênio da primeira crítica dobrando os joelhos à moral cristã na segunda crítica; afinal, embora tenha sido o filósofo que mais compreendeu que nossa crença num mundo inteligível tem sua raiz na ordem moral, "ele acreditou ingenuamente que nossa moral, longe de ser um preconceito, poderia ser racional" (Para além do Bem e Mal § 24). Na verdade, sua notoriedade se deve ao seu sucesso de teólogo. $O$ que seria da vida humana se não houvesse um ser que julgasse em última instância a intencionalidade do sujeito moral? 'Se não posso provar sua existência no campo da razão pura, a necessidade no campo da moral prática me faz agir como se ele existisse', "elucubrações que exprimem o declínio, o último grau de enfraquecimento da vida, a chinoisierie königsbergiana" ${ }^{10}$ Em Hegel, seu sistema, reduzindo tudo a uma tríade, faz com que a realidade dinâmica (Wirklichkeit) encontre sempre sua razão de ser e que os fatos, ainda que nem sempre lhes seja passível a identificação, encontrem forçosamente as suas causas pela necessidade do próprio sistema. Para Nietzsche, o historicismo hegeliano é o antípoda do sentimento trágico, o único capaz de dizer um irredutível "sim" à vida, apesar de todas as suas contradições. O sentimento trágico não é movido pela busca incansável das causas, pois sabe que há momentos da existência em que sua identificação se mostra impossível. Na ausência de sua identificação, ele não se apressa em identificar uma causa qualquer, mas aponta para o futuro e para as formas de enfrentar a rude situação. ${ }^{11}$ Finalmente, em Schopenhauer: apesar de sua genialidade em afirmar a força da Vontade e seu primado sobre a razão, a sua ética, baseada no sentimento de compaixão (Cf. NIETZSCHE, § 7, 1992b, p. 165), esconde um verdadeiro medo de viver. Se ele teve a coragem de pensar além da doutrina pregada pelo Cristianismo, afirmando que a presença do mal existe desde o início da criação (Gaia Ciência § 357), ele não teve a força de admiti-lo e de afirmálo na vida. Sua moral é uma renúncia à vida, é uma capitulação diante de tudo o que ele mostrou de forte e valoroso no início de sua obra maior: O Mundo como Vontade e Representação.

10 NIETZSCHE, § 11, 1992b, p.168.

11 Para Nietzsche à força de encontrar sempre uma causa para o sofrimento cai-se no risco de encontrar sempre um culpado contra o qual possamos dirigir todo nosso ressentimento. $\mathrm{Na}$ falta de um culpado real, encontra-se um culpado a qualquer custo, mesmo que seja para fazer passar o ódio que se lhe corrói. 
Opondo-se a toda esta capitulação, sistematizando o seu apelo em permanecermos fiéis à terra, apresentado de forma poética no Prólogo de Assim Falou Zaratustra, Nietzsche lança mão de todo o seu conhecimento teórico e retórico, bem como de toda sua vasta cultura no campo filológico e teológico, para combater o Cristianismo e seu corolário: a moral cristã.

No Cristianismo, nem a moral nem a religião têm o menor contato que seja com a realidade. Nelas não há mais do que "causas" imaginárias ("Deus", "alma", "livre arbítrio", - ou mesmo "servo arbítrio"); e efeitos imaginários: "pecado", "redenção", "graça”, "expiação", "remissão dos pecados" [...] Este mundo de pura ficção se distingue - em toda sua desvantagem - do mundo dos sonhos, pelo fato que este último reflete a realidade, ao passo que o primeiro a falsifica, e desvaloriza e nega a realidade. A partir do momento em que inventaram a palavra "natureza" para opor à idéia de "Deus", a palavra "natural" se torna notoriamente sinônimo de "condenável". Todo este mundo de ficção se enraíza no ódio ao natural (- a realidade!); ele é a expressão de um profundo mal estar diante do real [...]. (NIETZSCHE, § 15, 1992b, p. 172).

Nos primeiros parágrafos do Anticristo, Nietzsche procura desestabilizar os valores e as virtudes caros à moral cristã, tais como compaixão e a bondade para com os fracos e desvalidos (caridade?). Por meio de uma ironia que beira o sarcasmo, procura demonstrar que tais sentimentos não passam de debilidade em relação à vida, já que a compaixão faz com que o sofrimento se estenda sobre ela como uma espécie de contágio. Não podemos nos esquecer de que vida é também sofrimento, e os trágicos compreenderam isso. Não é necessário, portanto, alastrá-lo além do que lhe é devido. Para Nietzsche, hostilidade à vida é, em suma, o que se esconde por detrás da compaixão cristã, do qual Schopenhauer faz a apologia. Não é à toa que ele a tomou como a maior das virtudes (Cf. NIETZSCHE, § 7, 1992b, p. 164-165).

Ao mal-estar diante do real segue o espírito de décadence, que exprime uma fraqueza, uma vontade de nada diante da vida. É a mesma vontade de nada que se vê no Budismo, mas com uma desvantagem: este não declara guerra ao "pecado" (entenda-se aí o mundo real com suas relações sociais e políticas), mas ao sofrimento. Para Nietzsche, ele é cem vezes mais realista que o Cristianismo:

Uma atitude refinada em relação ao sofrimento, além de um caráter hipercerebral, uma longuíssima existência entre as abstrações e as operações lógicas, no curso da qual o instinto pessoal ficou em desvantagem em benefício do "impessoal”. (NIETZSCHE, § 20, 1992b, p. 177). 
No Budismo, aspira-se como bem supremo a paz, a extinção de todo desejo (Nirvana), e se alcança este fim. O mesmo não acontece com o Cristianismo. A exemplo do que acontece com o Judaísmo, nele não vemos o combate ao sofrimento, mas, antes, o combate ao pecado; ou melhor, o combate ao agente do pecado; o ódio ao pecador. Se no Budismo se busca a pureza, o mesmo não acontece com o Cristianismo, pois, se assim o fosse, não se teria tomado como primeira medida o fechamento dos banhos públicos logo após a expulsão dos Mouros na Península Ibérica. ${ }^{12}$ Ao ironizar sobre o fato, Nietzsche procura ilustrar que os cristãos, em vez de buscar a pureza, acabam por "sujar" tudo o que é belo e forte na vida: "por isso seu ódio em relação aos sentidos, às alegrias dos sentidos, à alegria em geral [...]" (NIETZSCHE, § 21, 1992b, p. 178). Com efeito, contrariamente ao que se poderia pensar, o Cristianismo não foi uma corrente religiosa que se opôs ao Judaísmo, mas seu aprimoramento. No Cristianismo, não é somente o ressentimento que reina, tal qual no Judaísmo; acrescente-se aí a má-consciência: ódio voltado contra si mesmo, a causa da infelicidade encontrada em seu próprio ser e não em um outro:

Na minha Genealogia da Moral, eu expus pela primeira vez a psicologia da oposição entre uma moral aristocrática e uma moral do ressentimento, a segunda resultando de um Não oposto à primeira: eis a moral judaicocristã no estado puro. Para poder dizer não a tudo o que representa o sentimento ascendente da vida, o sucesso físico, a potência, a beleza, a aceitação de si, o instinto do ressentimento, que tem seu traço de gênio, devia inventar um outro mundo, a partir do qual esta conquista vital (aquiescement) aparecia como um mal em si, como o que se devia rejeitar. (NIETZSCHE, § 24, 1992b, p. 183).

Para Nietzsche, não há dúvida: "a palavra Cristianismo repousa sobre um mal-entendido: no fundo, houve somente um cristão, e ele morreu sobre a cruz" (NIETZSCHE, §39, 1992b, 198). Quem inventou o Cristianismo não foi Jesus, mas seus discípulos, em particular o apóstolo Paulo: "O que, mais tarde, Paulo completou com a cínica lógica de um rabino não era mais que o processo de degradação que começou com a morte do Redentor" (NIETZSCHE, § 44, 1992b, p. 204).

Contrariamente ao que se poderia pensar, o Judaísmo não forma um povo decadente, a exemplo do que acontece com o Cristianismo. Aliás, os

12 Segundo Nietzsche, havia 270 destes banhos somente na cidade de Córdoba (Cf. NIETZSCHE., $\S 21,1992 b$, p. 178).

Rev. Filos., v. 19, n. 24, p. 79-109, jan./jun. 2007 
judeus são o oposto de todos os decadentes. Por um golpe de mestre, eles souberam se utilizar dos instintos decadentes para se colocarem no topo da pirâmide. Eles se utilizaram desse instinto para se impor "contra o mundo", o mundo dos fortes do qual eles haviam perdido seu lugar. Este povo de sacerdotes (mestres), reduzido à condição de escravo, soube encontrar os meios para erigir algo mais forte que todo o partido que diz "sim" à vida (aristoi). Na verdade, os judeus quiseram viver; quiseram se afirmar, ser "a qualquer preço". Na intenção de se dar um mundo, eles acabaram por inventar um mundo: o do puro e do impuro. Este mundo de repartição entre pureza e impureza não foi mais do que o artifício do povo judeu para se impor diante daqueles que o oprimiam; artifício de uma vontade de potência que visava ao poder. Por tudo isso, não se pode dizer que são decadentes, mas, por outro lado, são uns ressentidos.

É no tocante ao ressentimento que Nietzsche desenvolve sua análise sobre um aspecto positivo da práxis de Jesus. Nos parágrafos 32, 33 e 34, Nietzsche esboça um perfil de Jesus. Ele é o grande apaziguador, o homem manso, o "bom", o homem dos instintos frágeis, que traz o "Reino de Deus" em seu coração; em seu coração suave e de vida débil; este "Reino" que ele nos recusa apresentar de forma sistematizada, pois o "Reino" "não é algo que se possa esperar; ele não tem nem ontem e nem depois de amanhã, ele não virá "em mil anos" - é a experiência de um coração: ele está em toda parte, e em nenhum lugar $[\ldots]^{13} \mathrm{~A}$ idéia que ele tem de vida, do "Reino", manifesta-se por meio de uma realidade interior por meio da qual ele repugna tudo o que é fixo e se estabelece de forma exterior: a letra, a fórmula, a lei, a crença, o dogma. "Ele não fala de outra coisa a não ser do que é interior: "vida", "verdade" e "luz" são os nomes que ele atribui a este mundo interior - todo o resto, toda a realidade, a natureza inteira, até mesmo a língua, têm para ele somente o valor de um símbolo". ${ }^{14}$ Tudo tem para ele valor simbólico, aliás, sua noção de Reino está "para além de toda a história, ciência natural, experiência do mundo, todos os conhecimentos, toda a política, toda a psicologia; de todos os livros, de toda arte". ${ }^{15}$

13 NIETZSCHE, § 32, 1992b, p. 192. Nietzsche parafraseia neste parágrafo a passagem de Lc 17, 20-21.

14 NIETZSCHE, § 32, 1992b, p. 192.

15 NIETZSCHE, $\S 32,1992$ b, p. 192. Para elucidar esta passagem, vale lembrar que Nietzsche se baseia nas recentes descobertas dos exegetas bíblicos de seu tempo, para os quais muito do que se encontra nos evangelhos tem valor simbólico. Para os exegetas de nosso tempo, esta afirmação não apresenta problema nenhum, pois se sabe que os evangelistas não quiseram fazer uma crônica da vida de Jesus, mas a apresentaram-no, assim como a sua mensagem, seguindo um plano preestabelecido pelo autor. Colocar Jesus na Montanha (Mateus), ou na planície (Lucas), por ocasião do anúncio das bem-aventuranças, depende da intencionalidade do autor teológica.

Rev. Filos., v. 19, n. 24, p. 79-109, jan./jun. 2007 
$\mathrm{Na}$ verdade, Jesus não apresenta nenhuma teoria, não existe nenhuma doutrina, nenhum pensamento sistematizado, mas somente uma práxis baseada no amor: ele "não se encoleriza, não faz reprovações, não se defende: não porta espadas". ${ }^{16}$

A bem-aventurança de Jesus se caracteriza, pois, por sua maneira de aceitar a vontade do Pai, num abandono à sua vontade. Mais que uma crença, a bem-aventurança é o "sim" dado ao momento presente, vivido como a única realidade:

Paul Valadier traduz com propriedade o que esta bemaventurança significa para Nietzsche:

Viver no sentimento de que a totalidade do real entretém consigo uma relação plena (de paternidade) ou se reconhecer a si mesmo numa relação filial com esta totalidade, formam o verso e o reverso de uma mesma atitude. Não se trata mais de uma atitude una, parcial, limitada, exclusiva, mas de uma abertura graças à qual se percebe a si mesmo no seu enraizamento, ou o que é equivalente, na qual a gente percebe a superabundância viva, amante, paternal, da realidade.

Para aquele que, estando assim aberto a este sentimento da presença, se deixou invadir pela bem-aventurança, "Deus" não está mais situado numa distância separadora, exterior à existência. [...] Sentir-se filho de Deus consiste, portanto, em sentir-se como que divino (mas não Deus), capaz de viver numa relação sem relação descontínua com o que é. [...] No entanto, o acesso ao sentimento de filiação ou a entrada na bem-aventurança pressupõe o esquecimento de si do indivíduo, seu desaparecimento, e não sua exaltação descabida. É por causa disso que Jesus não exalta a pessoa, antes a convida a se esvaziar, a se apagar. "salva-se a vida pessoal da morte vivendo a vida universal" (Fragments Posthumes 1888-1889 11 (256)). (VALADIER, 1974, p. 414-415).

16 NIETZSCHE, 1992.

Rev. Filos., v. 19, n. 24, p. 79-109, jan./jun. 2007 
Georges Morel (1985), ao analisar estas passagens do Anticristo, apresenta o sentido que Nietzsche quer aplicar à práxis do Cristo, a exemplo de Paul Valadier, quer dizer: a fé crística não formulada, vivida, aliás, que se priva das fórmulas. Até mesmo a imagem que Jesus tem de Deus é particular: ele não tem uma noção de um "Deus pessoal" e recusa todo e qualquer antropocentrismo ao falar de Deus. Ele não tem nenhuma imagem preconcebida de um mundo anterior (ein Hinterwelt - mundo ideal segundo a concepção platônica). Nele, não se vê nenhum pensamento anterior (arrière pensée): ${ }^{17}$

Em outros termos: a santificadora visão anterior (sanctifiante arrièrevue) sobre a qual se funda a vida de Jesus significa que esta vida permanece essencialmente aberta, o contrário de um sistema fechado e antropocêntrico. (MOREL, 1985, p. 332).

Assim, livre de qualquer estrutura, Jesus se separa também da estrutura sacerdotal judaica (NIETZSCHE, § 27, 1992b, p. 187). Ele não é um sacerdote, segundo Nietzsche, ${ }^{18}$ ele não pertence à classe dos mestres mentirosos:

Mais profundamente, Jesus rompeu com o universo do ressentimento religioso e moral. É por isso que a palavra insurreição (Aufstand) não lhe é aplicável: o Cristo não é um revoltado. Ele não tem mesmo o ressentimento contra o ressentimento: ele deixou o mundo do ódio, onde ele nasceu, para ir para outros lugares. (MOREL, 1985, p. 329).

\footnotetext{
${ }^{17}$ Ao fazer um comentário sobre a apreciação de Nietzsche a respeito do amor de Jesus pela humanidade, baseado numa santificadora "visão anterior" (Hinterabsicht), Morel cita o aforismo 60 de Para além do Bem e do Mal no qual Nietzsche faz menção ao caráter nobre e fino do Cristo ao propor que se deva "amar os homens por amor a Deus", demonstrando que amar os homens sem a visão de uma realidade maior que a da realidade humana "é uma besteira e uma brutalidade a mais". Segundo Nietzsche, somente por esse pensamento Jesus "deveria tornar-se para nós sagrado e digno de veneração".

18 A Carta aos Hebreus, por outro lado, vai associá-lo à antiga estrutura do Templo, denominandoo o Sumo sacerdote por excelência. A exegese contemporânea não atribui a Paulo a autoria desta carta e Nietzsche certamente deveria saber, já que a autoria desta carta atribuída a Paulo já fora contestada por Clemente de Alexandria e Orígenes. No entanto, a forma como ela dá sustentação à tese de Nietzsche que apresenta o apóstolo de Tarso como aquele que associará Jesus ao Judaísmo e a tudo o que o seu mestre teria se oposto. A institucionalização da religião cristã seria para Nietzsche uma invenção de Paulo e não de Jesus (Cf. NIETZSCHE, 1992b, Anticristo §s 42; 47).
}

Rev. Filos., v. 19, n. 24, p. 79-109, jan./jun. 2007 
A fé de Jesus não é uma fé conquistada por meio de lutas... ela é uma fé sem rancor e que não cria discórdias. "A "Boa Nova" é justamente que não há mais oposição; que o "Reino dos Céus pertence às crianças" (NIETZSCHE, § 32, 1992b, p. 191). Por tudo isso, é que se poderia, "ainda que com alguma reserva", chamar Jesus de um "espírito forte", pois ele não se deixou vencer pelo ressentimento.

Mas por que "com alguma reserva" poderíamos denominá-lo assim? Ao responder esta questão, encerramos este tópico a respeito da práxis de Jesus. Para Morel, a mesma razão que faz com que a fé de Jesus seja aberta, isto é, a inexistência de um projeto preconcebido é que faz também que ele passe por "infantil", ou "idiota", para fazer referência à personagem de Dostoijewski. Infantil e idiota não no sentido vulgar, mas no sentido de inocente, estúpido por excesso de bondade (NIETZSCHE, § 31, 1992b, p. 190). O seu simbolismo, sua fé interiorizada, faz com que a realidade concreta seja desprezada. Na verdade, o "sim" de Jesus à vida carece de um "não" a tudo o que se opõe a esse "sim". Isto é, a liberdade interior de Jesus faz da liberdade um sonho. Ainda que este sonho não venha acompanhado de vingança, ele deixa intacta a escravidão:

Se o Cristo recusou a negação reativa, ultrapassando por um prodigioso vôo o mundo da revolta, ele também recusou a negação da afirmação magistral: um sim que não sabe dizer não à fraqueza que mina a história não é um verdadeiro sim. A ação do Cristo não passa de passividade. (MOREL, 1985, p. 334).

Na verdade, voltando-se somente para o mundo interior, Nietzsche apresenta Jesus como um anarquista sagrado que desprezou os raros elementos que restaram sãos no judaísmo: o mínimo de organização política. "Neste sentido, a despeito das aparências, ele não prestou um serviço aos escravos. Certo, à vida modesta e atenciosa das pessoas mais simples ele deu "um sentido e um valor mais elevados", mas na imaginação, e ao fazer isso ele as enganou" (MOREL, 1985, p. 335).

Com isso, Nietzsche pretende dizer que Jesus não tinha um suporte teórico para sua prática. Embora sua vida se resumisse a uma práxis sem ressentimento, a inexistência de uma base teórica conduziu os cristãos a um mundo da imaginação e consequientemente a uma alienação, onde as contradições sociais, econômicas e políticas estariam resolvidas internamente, na conversão do coração. 
Com efeito, as críticas que Nietzsche endereçou ao Cristo tinham por objetivo minar as bases do Cristianismo adocicado, piedoso e moralizante de sua época (FINK, 1984, p. 161). Seu ponto de vista é o de um retórico cuja persuasão tem por escopo desmoralizar as bases da moral cristã. "Nicht Theorie und Práxis trennen", disse Nietzsche em um de seus aforismos publicados postumamente. No entanto, para que a justiça seja feita, é preciso averiguar se a práxis de Jesus carecia realmente de um suporte teórico.

$\mathrm{Na}$ segunda parte deste artigo, partindo de um ponto de vista filosófico e lançando mão de alguns elementos da exegese teológica contemporânea, analisaremos a práxis de Jesus sob um outro ângulo, demonstrando a face política e afirmativa do seu modo de ser.

\section{Considerações filosóficas e contribuições teológicas a respeito da práxis da libertação e a práxis de Jesus}

\section{Práxis de Jesus como expressão de um projeto teórico de libertação para o ser humano}

No Evangelho de Mateus, vemos Jesus se dirigindo aos discípulos nos seguintes termos: "Guardai-vos dos falsos profetas, que vêm a vós disfarçados de ovelhas, mas por dentro são lobos ferozes. Pelos seus frutos os reconhecereis" (Mt 7, 15). Mais adiante, numa outra passagem, ele acrescenta: "Eis que eu vos envio como ovelhas entre lobos. Por isso, sede prudentes como as serpentes e sem malícia como as pombas".

Já em Assim Falou Zaratustra, vemos o profeta se dirigir aos seus discípulos da seguinte forma: "Aqui vedes sacerdotes; e, ainda que sejam meus inimigos, passai por eles em silêncio e com a espada dormindo na bainha. Também entre eles há heróis; muitos deles sofreram demais; querem, assim, fazer os outros sofrer” (Parte II - Dos Sacerdotes).

Estas passagens externam a preocupação dos profetas em aconselhar seus discípulos ao exercício constante da prudência. Nas entrelinhas, ambos externam a necessidade de que seus discípulos desenvolvam a sagacidade isenta de todo e qualquer ressentimento. Em ambos, se externa a preocupação dos mestres em orientar seus discípulos para que estejam sempre atentos a dizerem um "não" aos "grilhões de falsos valores e palavras ilusórias" (Parte II - Dos Sacerdotes). 
Para Jesus, prudência e desconfiança em relação aos falsos profetas é uma exigência estratégica, inerente ao anúncio da Boa nova e à instauração do Reino de Deus. Para Nietzsche, elas são necessárias à identificação da tirania que, julgandose possuidora absoluta da verdade, pretende dirigir o povo por intermédio da força e da massificação.

Ao fazer este pequeno paralelo, vemos que tanto Jesus quanto Zaratustra/Nietzsche têm uma razão para agirem assim; ao contemplarmos esses aconselhamentos, somos levados a afirmar que tanto a práxis de um quanto a do outro são movidas por uma intencionalidade. Afinal, não existe uma razão que os induza a agirem assim? Sua práxis seria um mero pragmatismo ou um aconselhamento alicerçado numa cosmo visão?

Se, por um lado, Nietzsche recusa ver uma intencionalidade articulada por parte de Jesus, em meio a uma comunidade concreta de discípulos, numa realidade sociopolítica específica, por outro, tomando a defesa do carpinteiro de Nazaré, poderíamos dizer que a intencionalidade de Zaratustra/Nietzsche se exprime por meio de uma proposta para "todos e para ninguém", carente de uma verdadeira práxis; afinal, não se dirige ele à tradição filosófica ocidental, sem contar com um discípulo sequer? É o próprio Nietzsche que atesta em uma de suas últimas cartas como seus dias estavam marcados por uma solidão total. Ao amigo Reinhart von Seydlitz, em carta datada de 12 de fevereiro de 1888 e expedida de Nice, Nietzsche escreve:

Eu me sinto neste momento muito só, absurdamente só. E, à força de uma luta implacável contra tudo o que os homens honraram e amaram até aqui, (minha fórmula para designá-lo é "inversão de todos os valores"), eu mesmo me transformei, imperceptivelmente, em algo parecido a um tatu, alguma coisa de escondido que não se encontra mais, mesmo quando se chega ao esgotamento para procurá-lo. [...] Na Alemanha, ainda que eu esteja nos meus quarenta e cinco anos, e que eu tenha publicado uma quinzena de livros (e entre eles, o nec plus ultra meu Zaratustra), nenhum, um único de meus livros foi submetido a uma única discussão, fosse ela de ummedíocre interesse. Valem-se deles com palavras tais quais "excêntrico", “patológico”, "psiquiátrico”. (NIETZSCHE, 1989, p. 60-61).

Assim, se por um lado Jesus apresenta a sua teoria sobre o "Reino de Deus" de forma simbólica, revelando-a por meio de parábolas a seus discípulos no caminho da Galiléia a Jerusalém, ${ }^{19}$ por outro, Nietzsche escreve

19 Eis algumas citações sobre as alegorias sobre o Reino apresentadas por Jesus (vide Mt 13 e as parábolas sobre o Reino ou Lc 17, 20; 18, 24-27). 
seus livros e não encontra um público que os leia, nenhum discípulo ou mesmo um amigo que compartilhe e vibre com suas idéias. Neste sentido, no seguimento das premissas de Nietzsche afirmando que Jesus tem somente uma práxis, não deveríamos afirmar também que o primeiro tem somente a teoria? A vida de Nietzsche e mais marcadamente os dias que antecederam sua imersão na loucura não estariam em contradição com sua intenção de jamais separar a práxis da teoria?

Em Crepúsculo dos Ídolos, Nietzsche procurou desmistificar a obra e a vida de outra grande personagem da história mundial: Sócrates. Para ele, o mestre de Platão, a exemplo de Jesus, também era um decadente. Sua "teoria" sobre a imortalidade da alma e a maiêutica como técnica de reminiscência para libertar a alma das limitações do corpo e do império dos sentidos não refletiam mais do que sua visão de um mundo ideal depreciando o mundo real, exaltando os elementos espirituais e menosprezando os corporais. No primeiro parágrafo desta obra, Nietzsche aponta para uma característica comum aos discursos dos grandes sábios quando eles passam a julgar a vida: "um tom (Klang) de dúvida, de melancolia, de lassidão de viver, de resistência à vida". Tonalidade que se faz perceber em Sócrates no momento de morrer: "A vida não é mais do que uma longa doença; eu devo um galo a Asclépio, o Salvador" (Crepúsculo dos Ídolos OProblema de Sócrates § 1). Mas, se seguirmos o que nos contam os seus biógrafos, Sócrates demonstrava pela práxis aquilo que pensava em teoria. A aplicação do método da maiêutica fugia a toda e qualquer atuação política permeada de orgulho e interesses privados e encontrava nas atitudes de seu mestre a legitimação para o verdadeiro exercício da política. Como vimos anteriormente com Hannah Arendt, o mestre de Platão via na retração e na pertença do mundo o método para se buscar o Bem e, consequientemente, a realização humana. $\mathrm{O}$ thaumazein (retração e pertença ao mundo) foi posteriormente sistematizado por seus próprios discípulos e se tornou uma prática corrente na Academia de Platão. ${ }^{20}$ Ao que parece, sobre isso, Sócrates nada escreveu. Nem por isso ele não reservou para os seus discípulos momentos profundos de reflexão e sistematização dos princípios que norteavam suas ações; nem por isso se poderia dizer que sua práxis não tinha nenhum fundamento teórico.

20 À diferença de seu Mestre, que o fazia sem deixar o ambiente dialógico da Ágora, Platão aplicava a retração do mundo no ambiente recluso da Academia, por considerá-lo um ambiente propício ao exercício teórico desvinculado dos elementos nocivos da opinião agorística, permeada de interesses pessoais, nem sempre comprometidos com a busca da verdade. É o que afirma Gerard Lebrun em sua obra Sócrates, Platão e Aristóteles e Giovanni Reale, ao revisitar certos temas dos diálogos platônicos à luz de um novo paradigma: o da tradição não-escrita testemunhada no Fédon e na Carta VII de Platão.

Rev. Filos., v. 19, n. 24, p. 79-109, jan./jun. 2007 
A exemplo de Sócrates, que nada escreveu, não teria Jesus nenhum componente teórico fundamentando sua ação? Hannah Arendt, na obra Human Condition, apresenta a doutrina do perdão como uma práxis baseada numa racionalização, ou seja, cujo sentido tem por motivação uma razão, uma racionalização e não mera intuição. Elaborada por Jesus Cristo, a doutrina do perdão apresentou-se como antídoto aos problemas colocados pela imprevisibilidade inerente à ação. Segundo Hannah Arendt, é somente com Jesus de Nazaré, com seu ensinamento do perdão, que o mundo das coisas humanas pode ver uma solução legítima para a irreversibilidade da práxis. ${ }^{21}$ Para a filósofa judia, contrariamente à vingança, que é a reação natural à transgressão e por isso está "longe de colocar fim às conseqüências da primeira falta", o perdão "é a única reação que não se limita a re-agir, mas que age de maneira nova e inesperada, não condicionada pelo ato que a provocou e que conseqüentemente libera ao mesmo tempo das consequiências do ato aquele que perdoa e aquele que é perdoado". ${ }^{22}$ Potente na sua capacidade de gerar uma situação nova e recomeço, o perdão é um fenômeno intrinsecamente ligado ao amor. É o que disse Jesus em relação à pecadora: "seus pecados, seus numerosos pecados, lhe foram perdoados porque ela mostrou muito amor" (Lc 7, 47).

Com isso, pretendemos demonstrar que a crítica de Nietzsche dirigida à pessoa de Jesus tem como finalidade colocar em descrédito a pessoa e a mensagem do mestre de Nazaré, lançando mão de sua retórica e de uma visão unilateral da sua vida e de sua doutrina, beirando o ressentimento e o ódio que tanto combateu. Tudo isso em razão de seu projeto maior: combater a moral judeu-cristã e efetivar verdadeira transmutação dos valores.

No tópico seguinte, finalizaremos esta exposição apresentando os elementos que norteavam teoricamente a práxis de Jesus, os reflexos que vemos incidir sobre a práxis da libertação.

21 ARENDT, Hannah. La Condition de l'homme moderne, 1988, p. 304. No capítulo dedicado à análise da doutrina do perdão desenvolvida por Jesus, Hannah Arendt a apresenta como uma contribuição importante ao problema da ação inconseqüente ou maléfica para o conjunto social. Como refazer, a exemplo do que se pode fazer com a poiésis, uma ação reverter à intenção inicial? Somente o perdão torna isso possível. O reconhecimento da falta por parte do infrator, por meio do qual ele atesta que o resultado da sua ação não corresponde ao que era devido, aliado à concessão do perdão por parte daquele que foi lesado por ela, possibilita que se recomece do marco inicial, sem ressentimento e sem vingança. É o que Hannah Arendt denomina de antídoto contra à irreversibilidade da práxis.

22 ARENDT, Hannah. La Condition de l'homme moderne, 1988, p. 307. 


\section{A noção teórica de "Reino" imanente à práxis libertadora de Jesus.}

Como vimos anteriormente, para Nietzsche, a bem-aventurança vivida por Jesus caracteriza-se por viver em contato direto com Deus, sem ritos e fórmulas, constituindo-se na única realidade anunciada por ele e na essência da sua "Boa Nova" (Cf. NIETZSCHE, § 33, 1992b, p. 193). Esta visão beatífica de Jesus contrasta com a visão que os evangelistas tiveram dela. No Anticristo, Nietzsche aponta para a compreensão equivocada dos discípulos: no lugar de uma nova maneira de viver, segundo a vontade divina, Nietzsche vê na sua elaboração a vitória da moral dos escravos, quer dizer, a moral dos apóstolos de Jesus (que, segundo ele, não souberam compreender sua mensagem e, consequientemente, não puderam realizar este estado beatífico em suas próprias vidas, submetendo-se ao ressentimento dos judeus). Para Nietzsche, o Discurso da Montanha recebe sua credibilidade devido a sua oposição à moral corrente e, sobretudo, porque ele faz com que os fracos se identifiquem com sua fraqueza. Neste sentido, porque o ideal é apresentado como o primeiro identificado à fraqueza, a fraqueza pode, por sua vez, identificar-se com este ideal:

O fraco não pode, com efeito, suportar a distância do livre jogo entre os valores: ele quer fixá-los e assim se identificar com eles, ao menos imaginariamente. O fraco representará, portanto, este ideal e será sua presença no mundo sob a forma de sua encarnação, retomando o processo pelo qual o povo judeu se identificou com a eleição e se separou dos outros. (VALADIER, 1974, p. 371).

Jacques Dupont (1978), exegeta contemporâneo, está de acordo com Nietzsche em ao menos um ponto no que diz respeito às bem-aventuranças de Jesus: as que são apresentadas pelos evangelistas não representam completamente o conteúdo da bem-aventurança vivida pelo mestre. Segundo ele, ao apresentar o discurso inaugural do mestre Jesus na montanha, Mateus o apresenta por meio do anúncio de dez bem-aventuranças, sendo que a última ele a desdobra em duas: "felizes sois, quando vos injuriarem e vos perseguirem e, mentindo, disserem todo mal contra vós por causa de mim (a); Alegrai-vos e regozijai-vos, porque será grande a vossa recompensa nos céus, pois foi assim que perseguiram os profetas que vieram antes de vós (b)" (Mt 5, 12). Lucas, por outro lado, apresenta somente quatro, sendo que a última, como em Mateus, desdobra-se em duas e são seguidas de quatro repreensões ("Ai de vós ricos, pois já tendes a vossa consolação.”). Em ambas as versões, redigidas por volta 
dos anos 64 e 70 d.C., é anunciada uma única coisa: a felicidade, a alegria de viver a todos os que disso são privados. Marcadas pelo tempo, as bemaventuranças na versão de Mateus, embora anunciadas a uma comunidade de judeus convertidos ao cristianismo, dirigem-se para toda a humanidade; ao passo que as de Lucas são dirigidas preferencialmente a uma comunidade de pagãos convertidos ao cristianismo e perseguidos por causa de Cristo. Situados num tempo em que a perseguição aos cristãos começa a tomar fôlego, ambos colocam a promessa de felicidade num tempo vindouro, em relação à situação de penúria do tempo presente: Felizes os que têm fome "agora", porque serão saciados, é o que Lucas quer dizer (Lc 6, 21). O deslocamento para um tempo futuro do estado de felicidade anunciado por Jesus é dado pelo deslocamento textual de uma vírgula. Ela acentua o tempo ao qual Lucas faz referência: aquele em que os cristãos têm fome. Segundo Dupont, Jesus teria dito: "Felizes os que têm fome, "agora" serão saciados", anunciando o tempo de felicidade que sua presença inaugura entre aqueles que passam (materialmente) fome. Jesus, assim como o próprio Nietzsche escreveu, não faz alusão a um tempo futuro, mas ao tempo da conversão do coração que inaugura o Reino de Deus no interior do ser humano. Neste sentido, as opiniões de Dupont e de Nietzsche parecem coincidir, não fosse uma diferença radical: para Nietzsche, trata-se somente de conversão do coração (inocência infantil de Jesus - o idiota); para Dupont, no entanto, trata-se de um novo projeto de vida que, embora não clame por violência e vingança, ${ }^{23}$ anuncia sim uma transformação político-social.

A razão que leva Dupont a afirmar a dimensão sociopolítica da mensagem de Jesus é a seguinte: com seu modo de agir, Jesus rompe com a concepção de um justiceiro terrível, anunciada e esperada por João no deserto. Jesus chega mesmo a decepcioná-lo. Quando "Batista", um profeta impregnado das Escrituras, ordena a seus discípulos irem até Jesus para lhe perguntar se ele é verdadeiramente o Messias, este lhes responde: "Ide contar a João o que ouvis e vedes: Os cegos recuperam a vista, os coxos andam, os leprosos são purificados e os surdos ouvem, os mortos ressuscitam e os pobres são evangelizados. E bem-aventurado aquele que não se escandalizar por causa de mim" (Mt 11,4-6). Jesus apresenta a João os sinais concretos do Reino preditos por Isaías (Is 26, 19; 29, 18-19).

23 É interessante frisar que no discurso inaugural da Sinagoga de Nazaré (LcLc 4, 16-29), Jesus ao ler a passagem de Isaías (Is 61, 1-2) omite o versículo "e o dia da vingança de Yahweh" (v. 2b). Seu Reino é de paz, não de revanche. Esta omissão causou-lhe a expulsão de Nazaré, a cidade em que vivia e pela qual era conhecido (Jesus o nazareno), pelo simples fato que a Galiléia era conhecida por ser a terra dos insurreitos e dos que clamam vingança ao Senhor. Omitir este versículo era frustar a manifestação desse sentimento. 
Segundo Dupont, as bem-aventuranças de Jesus, em Mateus, estão ligadas a valores e perspectivas messiânicas da história de Israel, realizadas de uma forma diferente à esperada pelos galileus: elas restituem aos pobres de espírito, os anawin ruah - que não são capazes de resistir ou de se defender e que experimentam ao mesmo tempo a humildade, a paciência e a doçura ${ }^{24}$ - a sua dignidade enquanto filhos-herdeiros de Deus, na medida em que os ensina a chamarem-no de Pai. Elas se dirigem aos mansos, àqueles que não se "esquentam" e por isso não perdem o bom-senso no dirigir sua vida, são os não-violentos por excelência e que não se deixam vencer pelo ressentimento e jamais perdem a esperança de ver esta vida se transformar; sua mensagem é voltada aos "misericordiosos", àqueles que sabem perdoar de todo o coração e por isso são capazes de revitalizar as relações humanas; que prestam socorro àqueles que passam necessidade e, por isso, aprendem a partilhar, e não a acumular. Além do mais, na perspectiva do Reino messiânico de Jesus, não há lugar para a disputa política baseada no privilégio e na tirania. Quando ele vê seus discípulos disputarem um lugar de honra em seu Reino, Jesus lhes adverte: "Sabeis que os governadores das nações as dominam e os grandes as tiranizam. Entre vós não deverá ser assim" (Mt 20, 25-26). Em Jesus, é o conceito de Reino que está em jogo. No anúncio do Reino de Deus proferido por Jesus, são as características do "rei ideal do Antigo Oriente" que são ressaltadas, dentre as quais destacam-se: o rei ideal deve assegurar a liberdade ao seu povo face aos povos estrangeiros (Ex 15); ele deve exercer uma missão libertadora no interior de seu povo, quer dizer, fazer com que o direito e a justiça sejam respeitados entre seus cidadãos. Já que os poderosos e os ricos têm uma tendência a explorar e a oprimir os fracos e os pobres, ele deve intervir e proteger os primeiros contra os ricos. ${ }^{25}$ Na perspectiva do Reino, segundo Isaías, todo o povo será libertado de suas penas. O contexto a partir do qual fala o segundo Isaías é muito concreto e não tem nada de abstrato: "é a lembrança dos horrores que precederam a deportação e o exílio da Babilônia: "os homens empalados, guerreiros decapitados, mulheres violadas, crianças jogadas contra os rochedos, fome, sede [...]" ${ }^{26}$ Para Isaías, a chegada do Reino de Deus responde a esta situação concreta:

24 DUPONT, Jacques. Les messages des Beatitudes de Jésus. Cahiers Evangéliques, n. 24, Cert., Paris, 1978, p. 44.

25 DUPONT, 1978, p. 16.

26 DUPONT, 1978, p. 13.

Rev. Filos., v. 19, n. 24, p. 79-109, jan./jun. 2007 
Modelei-te e te pus por aliança de meu povo a fim de restaurar a terra, a fim de redistribuir as propriedades devastadas, a fim de dizer aos cativos: "Saî", aos que estão nas trevas: "Aparecei." [...] Não terão fome nem sede, a canícula e o sol não os molestarão, porque aquele que se compadece deles os guiará, conduzi-lo-ás aos mananciais. [...] Ei-los que vêm de longe, uns do norte e do ocidente, outros, da terra de Sinim. Ó céus, daí gritos de alegria, ó terra, regozija-te, os montes rompam em alegres cantos, pois Yahweh consolou seu povo, ele se compadece dos aflitos. (Is 49, 9 - 13).

É, pois, a alegria de toda a criação que Jesus anuncia aos pobres que estão diante dele: "Felizes sois vós, anawim ruah, pois o Reino de Deus é vosso". Eis a Boa Nova de Jesus: O Reino de Deus não é impossível de conquistar, pois eis que ele está no meio de vós! (Lc 17, 21).

Para aqueles que crêem na palavra e alimentados pela práxis de Jesus, o Reino de Deus se faz já presente e não somente no interior do coração. $\mathrm{O}$ fato de Jesus não ter traçado nenhum plano para a instauração concreta do Reino não desmerece em nada sua proposta. Ele deixa teorizados os princípios e as bases que asseguram a felicidade humana, mas não os delimita num sistema qualquer. Os meios e as formas devem se ajustar segundo as possibilidades do tempo e do espaço, tarefa esta a ser realizada por todas as pessoas que, em comunidades, vivem segundo seu espírito. Nietzsche também se recusou a estabelecer sistemas. Aliás, recusou-se a estabelecer como correta uma única maneira de pensar e agir. Avesso aos sistemas fechados e às posições cristalizadas, ele ensinou, por intermédio da boca de Zaratustra, que 'o que faz o homem ser grande não é a meta, mas ele ser ponte'.

\section{Conclusão}

Nos anos 70 e 80, em toda a América Latina e particularmente no Brasil, a experiência das Comunidades Eclesiais de Base (CEB's), animadas pela práxis e a teologia da libertação, pôde externar o que significou a pessoa e as palavras de Jesus nos movimentos sociais contrários ao regime militar. Nelas, foi possível contemplar as bases de uma transmutação dos valores no combate ao consumismo; a organização social com vistas à participação política e melhores condições de saúde, moradia, trabalho e educação; o fortalecimento do espírito para não sucumbir à tentação do "entreguismo", da delação, da imobilidade, da passividade e do comodismo diante da opressão; por fim, a 
afirmação de um modo de vida oposto ao sistema ditatorial. Um "sim" seguido de um "não". No livro Brasil Nunca Mais, redigido pela Comissão de Justiça e Paz da Arquidiocese de São Paulo, contemplamos a resistência e o engajamento de centenas de pessoas torturadas e perseguidas por acreditarem que o Brasil pode ser um país mais justo; em cujo solo se pode lutar pela liberdade e por uma vida mais feliz, na qual a possibilidade de desenvolver as potencialidades é concedida a cada um, sem distinção de sexo, raça ou condição social.

A práxis de Jesus, testemunhada por membros das Comunidades Eclesiais de Base, trouxe um sopro novo à vida política e religiosa do país. Numerosos foram aqueles que puderam desenvolver seus dons e se experimentar enquanto sujeitos históricos. O poder emanado de suas mãos deflagrou greves, e enfrentaram a fúria dos soldados em meio a piquetes e protestos, colocando novamente nas urnas um voto livre e sem coação. Na égide de novos tempos e na construção de uma nova conjuntura política, a práxis das CEB's demonstrou que a religião, em particular o Cristianismo, longe de ser um instrumento de decadência e alienação, como disse Nietzsche no rastro de Feuerbach, pode se configurar numa Vontade de Potência a favor da vida.

Por meio dos bons encontros e da libertação de visões de mundo fechadas em si, as CEB's possibilitaram a partilha do pensamento e o surgimento de uma variedade de pastorais sociais e de organizações nãogovernamentais, como expressão de formas potenciais e diferenciadas de vida, destituídas das vaidades e dos interesses mesquinhos que caracterizam a luta pelo poder. Liberta de uma "caridade" puramente assistencialista, caracterizada mais pelo alívio de consciência do que pela inclusão social que promove, a práxis da libertação, ao se inserir no meio dos pobres, desenvolveu uma ação que os assiste em suas necessidades, oferecendo-lhes ao mesmo tempo um "instrumental" de análise, oferecendo-lhes pistas e estratégias para saírem de sua miséria e opressão. Enquanto "vontade afirmativa que doa", a práxis da libertação ofereceu às camadas sociais menos favorecidas a possibilidade de experimentarem a potencialidade que existe em sua organização. E, nisto, ela contesta a afirmação nietzschiana de que a mensagem de Jesus matou uma das poucas coisas sãs que ainda existia entre os judeus: a organização política. À diferença da ação puramente assistencialista, inspirada nas organizações filantrópicas e piedosas do século passado, a práxis da libertação foi ao encontro dos pobres, restabelecendo-lhes a confiança em sua luta por libertação. É somente nesse sentido que os agentes da práxis da libertação foram capazes de compreender as palavras de Nietzsche: "Nein", 
antwortete Zaratustra, "ich gebe kein Almosen. Dazu bin ich nicht arm genug". 27 Com efeito, quem é potente no sentido que Nietzsche emprega, é necessariamente dadivoso. Mas sua dádiva não se traduz na relação desigual entre beneficiário/ beneficiado. Quem dá esmolas vive numa situação superior àquele que a recebe, material e psicologicamente falando. Num certo sentido, receber uma esmola é humilhante e não abole a humilhação inerente ao ato. É por isso que Zaratustra não dá esmolas. Ser potente e dadivoso é também ter uma relação de desprendimento em relação aos bens materiais, para que lhe seja assegurada a liberdade de pensamento (teoria) e de ação (práxis), assim como o fez Jesus: "Ele, que tinha condição divina, esvaziou-se a si mesmo e assumiu a condição de servo" (Fl 2) - o esvaziamento proveniente de uma superabundância de vida em seu interior. Zaratustra também quer esvaziar-se, ou melhor, enquanto anunciador de um novo homem, em seu esvaziamento ele oferece à humanidade um caminho de emancipação: "Was ist der Affe für den Menschen? Ein Gelächter oder reine schmerliche Scham. Und ebendas soll der Mensch für den Übermenschen sein: ein Gelächter oder reine schmerliche Scham", dizia Zaratustra. ${ }^{28}$

É bem verdade que este novo modo de ser não deixou de ter lá suas tentações: uma resistência assaltada por ressentimentos e impregnada de um "ideal político" que mais desuniu do que aglutinou. Os ranços políticos, o "purismo" de determinados segmentos da sociedade, avessos a pactos responsáveis e coerentes, fizeram com que se caísse no "jeitinho brasileiro", nas saídas individualistas e comodistas em relação ao sistema contra o qual insistentemente se lutou. Esses entraves não podem deixar que estas experiências caiam no esquecimento. Penso que o espírito que animou as CEB's no tempo da ditadura, fossem elas de confissão católica ou protestante, deveria ser retomado nos momentos em que a descrença em relação aos organismos políticos imobiliza e leva a sociedade para uma desintegração e decepção e a uma adaptação a poderes paralelos sem nenhuma forma de controle e regulação.

Esvaziar-se é inerente à potência, eis um dos ensinamentos de Nietzsche e que ele soube tão bem expressar na poética dos Ditirambos de Dionísio, ao tratar Da pobreza do mais Rico. Ensinamento este que poderia reavivar nos doutos, em tempos de desencanto, de prostração e de desarticulação política, os ideais da práxis da libertação:

27 “Não", replicou Zaratustra, eu não dou esmolas. Eu não sou bastante pobre para isso." (Assim Falou Zaratustra - Prólogo § 2).

28 "Que é o macaco para o Homem? Motivo de riso ou de dolorosa vergonha? Tal será o homem para o que é acima do homem (Superhomem): motivo de riso ou de dolorosa vergonha. (Assim falou Zaratustra $§ 3)$.

Rev. Filos., v. 19, n. 24, p. 79-109, jan./jun. 2007 
Du siehst aus, wie einer,

Der Gold verschluckt hat:

Man Word dir noch

den Bauch aufschlitzen

[...] u opferst dich

Dich quält dein Reichtum

Du gibst dich $a b$,

Du schonst dich nicht,

Du liebst dich nicht:

Die grosse Qual zwingt dich allezeit,

Die Qual übervoller Scheunen

Übervollen Herzens

Aber niemand dankt mehr

Du musst ärmer werden

Weiser Unweiser!

Willst du geliebt sein.

Man liebt nur die Leidenden,

Man giba Liebe dem Hungernden:

Verschenke dich selbst erst, ó Zaratustra

- Ich bin deine Wahrheit...
Pareces-te a alguém

que engoliu ouro:

ainda te hão de abrir

a barriga

Tu te dás em sacrifício

Tua riqueza tortura-te

Tu te dás

Não te poupas,

Não te amas:

A grande tortura obriga-te sempre

A tortura dos celeiros repletos,

Do coração repleto

Mas ninguém já te agradece...

Tens de te fazer mais pobre,

Ó sábio Não-sábio!

Se quiseres ser amado.

Só se ama a quem sofre, só se dá amor a quem tem fome:

dá-te primeiro a ti, ó Zaratustra!

- Eu sou a tua Verdade... 


\section{Referências}

ARENDT, Hannah. Philosophy and Politics: what is political philosophy. Arent's Paper. Box 44. Washington D. C: The Library of Congress, 2001.

La Condition de l'homme moderne. Traduit de l'anglais par Georges Fradier. Imprimé en Angleterre: Calman Lévy, 1988.

ARNS, Paulo Evaristo. Brasil nunca mais. Petrópolis: Vozes, 1991.

COLLI, G.; MONTINARI, M. Friedrich Nietzsche: Oeuvres Completes. Tome VIII. Notes sur L'Antichrist. Paris: Gallimard, 1992.

DUPONT, Jacques. Les messages des Beatitudes de Jesús: Cahiers Evangéliques, n. 24, Cerf, Paris, 1978.

FINK, E. La Filosofia de Nietzsche. 6. ed. Madrid: Alianza, 1984.

NIETZSCHE, F. Dernières Lettres. Paris: Rivages Poches, 1989.

NIETZSCHE, F. Fragments Posthumes printemps 188814 [107]. Traduits de l'allemand par Jean Claude Hémery. Paris: Gallimard, 1992a.

L'Antichrist. Oeuvres Completes, tome VIII. Paris: Gallimard, 1992b.

MOREL, G. Nietzsche: Introduction à une première lecture. Paris: Aubier, 1985.

TAMINIAUX, Jacques. La fille de Thrace et le penseur professionnel: Arendt et Heidegger. Paris: Payot, 1992.

TURCO LIVERI, Giuseppe. Nietzsche: lessico dei concetti e dei nome delle opere nietzscheane. Roma: Armando-Armando, 1982.

VALADIER, Paul. Nietzsche et la critique du Christianisme. Paris: Du Cerf, 1974.

Recebido em/Received in: 20/02/2007

Aprovado em/Approved in: 13/03/2007 
